\title{
Neonatal quadricuspid truncal valve repair with left coronary artery unroofing
}

Igor E. Konstantinov, MD, PhD, FRACS, ${ }^{\mathrm{a}, \mathrm{b}, \mathrm{c}, \mathrm{d}}$ Stephanie L. Perrier, MD, ${ }^{\mathrm{a}}$ Phillip S. Naimo, MD, ${ }^{\mathrm{a}}$ and Yves d'Udekem, MD, PhD, FRACS, ${ }^{a, b, c, d}$ Melbourne, Australia

From the ${ }^{\mathrm{a}}$ Department of Cardiac Surgery, Royal Children's Hospital, Melbourne, Victoria, Australia; ${ }^{\mathrm{b}}$ Heart Research Group, Murdoch Children's Research Institute, Melbourne, Victoria, Australia; ${ }^{\mathrm{c}}$ Department of Paediatrics, University of Melbourne, Melbourne, Victoria, Australia; and ${ }^{\mathrm{d}}$ Melbourne Children's Centre for Cardiovascular Genomics and Regenerative Medicine, Melbourne, Victoria, Australia.

Philip S. Naimo was supported by National Health and Medical Research Council Scholarship number APP1150242.

Disclosures: Yves d'Udekem is consultant for Actelion and MSD. All other authors have nothing to disclose with regard to commercial support.

Received for publication Aug 3, 2018; revisions received Sept 10, 2018; accepted for publication Sept 12, 2018; available ahead of print Nov 2, 2018.

Address for reprints: Igor E. Konstantinov, MD, PhD, FRACS, Royal Children's Hospital, 50 Flemington Rd, Parkville, Victoria 3029, Australia (E-mail: igor.konstantinov@ rch.org.au)

J Thorac Cardiovasc Surg 2019;157:710-1

$0022-5223 / \$ 36.00$

Copyright $($ c 2018 by The American Association for Thoracic Surgery

https://doi.org/10.1016/j.jtcvs.2018.09.046

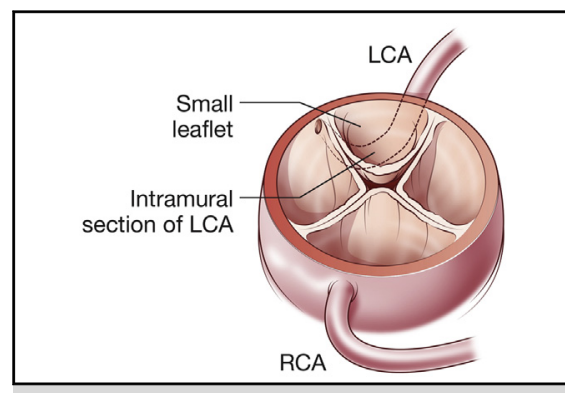

Neonatal quadricuspid truncal valve and ostial stenosis of intramural left coronary artery.

\section{Central Message}

Truncal valve tricuspidization with left coronary artery unroofing resulted in excellent repair in a newborn infant with truncus arteriosus and severe truncal valve insufficiency.

See Editorial Commentary page 712
Repair of a severely regurgitant truncal valve in a newborn infant is challenging. Herein we describe a surgical approach to repair a quadricuspid truncal valve in a neonate with concomitant ostial stenosis and intramural course of the left coronary artery (LCA). We performed a tricuspidization of the truncal valve with resection of the rudimentary cusp, reduction of the annulus and unroofing of the LCA, followed by ventricular septal defect patch closure and reconstruction of the right ventricular outflow tract.

\section{CLINICAL SUMMARY}

A newborn girl weighing $2.8 \mathrm{~kg}$ with type I truncus arteriosus and severe truncal valve insufficiency was referred to our institution with heart failure. The repair was undertaken at age 4 days through a standard midline sternotomy with hypothermic cardiopulmonary bypass $\left(30^{\circ} \mathrm{C}\right)$ and intermittent antegrade cold blood cardioplegia (Video 1). The truncal artery was transected and the branch pulmonary arteries were separated from the aorta. The LCA had a high take-off with stenotic ostium located immediately above the posterior commissure of the quadricuspid truncal valve and an intramural course (Figure 1, A). All 4 cusps of the truncal valve appeared thickened. The cusp adjacent to the LCA was rudimentary and prolapsing. The intramural segment of the LCA was unroofed. The corresponding sinus was longitudinally opened and the prolapsing cusp was partially resected together with the wall of its sinus. The cusp to the left of the resected cusp was mobilized by commissural detachment (Figure 1, B). The truncal root was reduced from the annulus to the sinotubular junction with a continuous 8-0 polypropylene suture (Figure 1, $C$ ), effectively decreasing the diameter of the neoaortic root. The same 8-0 polypropylene suture was continued to the cusp tissues to reconstruct a new left coronary cusp by suturing the remaining portion of the rudimentary cusp to the mobilized

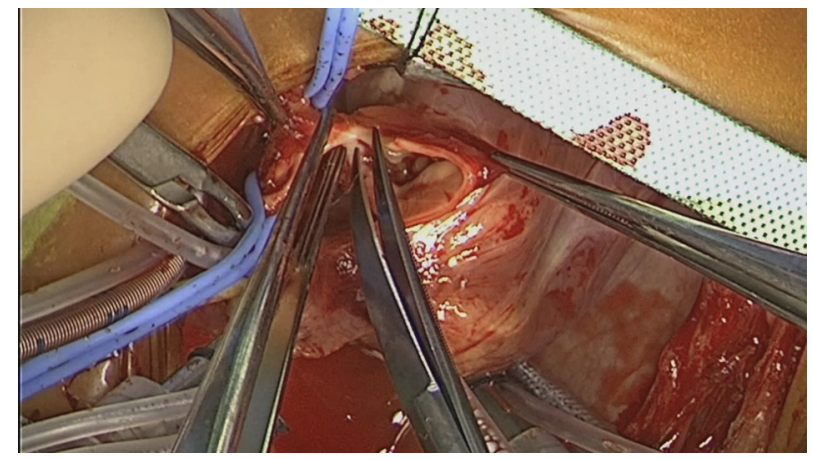

VIDEO 1. Intraoperative technique for the repair of common arterial trunk with severely regurgitant quadricuspid truncal valve and intramural left coronary artery in a neonate. Video available at: https://www.jtcvs.org/ article/S0022-5223(18)32550-9/fulltext. 

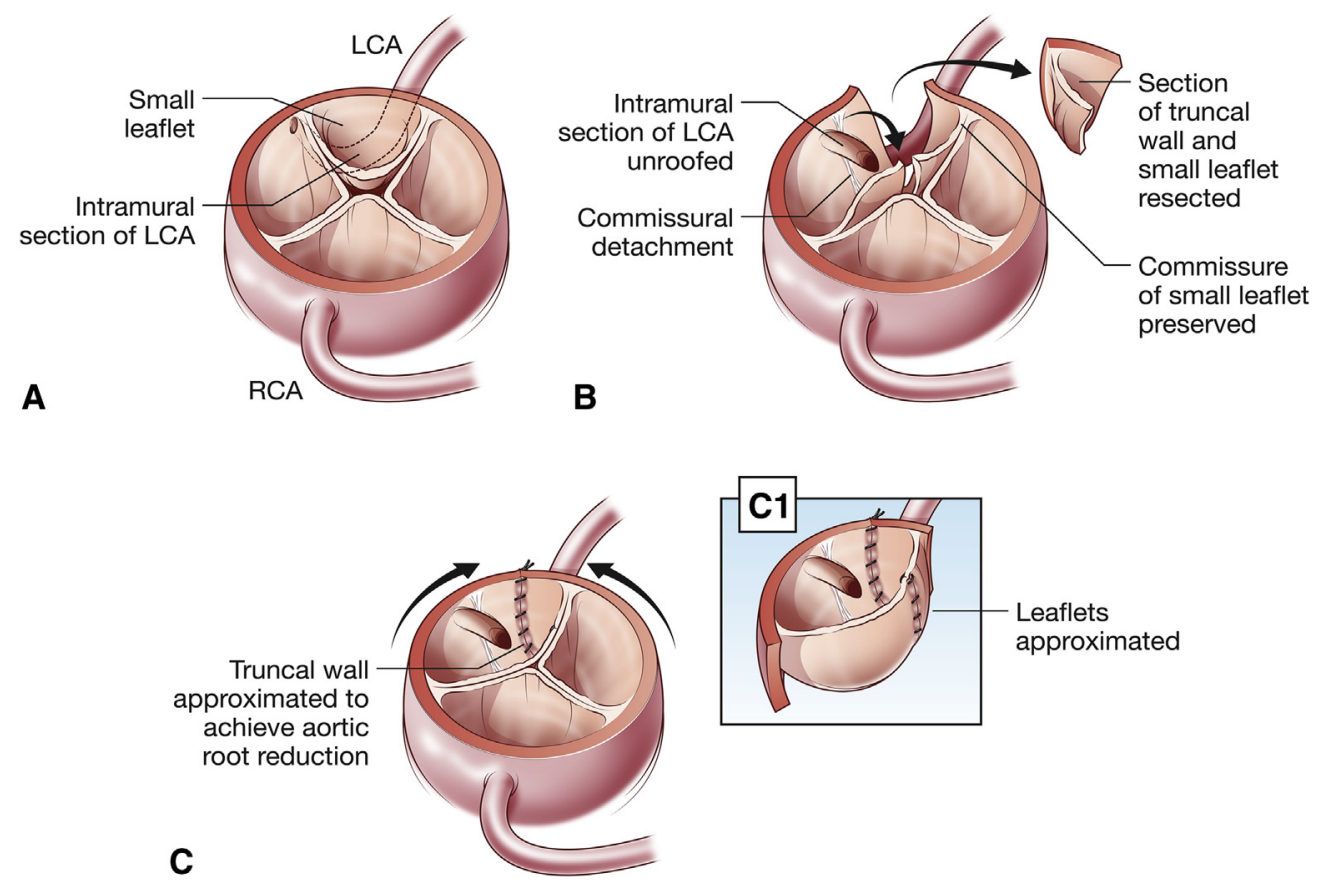

FIGURE 1. A, Quadricuspid anatomy of the truncal valve, position of the rudimentary cusp and the coronary arteries (A). B, Technique of repair with excision of the rudimentary cusp and sinus, unroofing, and detachment of the left coronary artery $(L C A)$. $\mathrm{C}$ and $\mathrm{C} 1$, reconstruction of the root and the valve with plication of the annulus. RCA, Right coronary artery.

posterior cusp (Figure 1, Cl) to achieve a normal trileaflet neoaortic valve anatomy. A right ventriculotomy was performed. The neoaorta was reconstructed primarily with end-to-end anastomosis. The ventricular septal defect was closed through the right ventriculotomy with glutaraldehyde-treated autologous pericardium using 60 pledgeted continuous polypropylene suture. A $10-\mathrm{mm}$ polytetrafluoroethylene graft was placed from the right ventricle to the confluent pulmonary arteries. Following de-airing, the aortic crossclamp was removed. Normal sinus rhythm was restored. The patient was separated from cardiopulmonary bypass. Epicardial echocardiography showed a tricuspid truncal valve with trivial regurgitation. Cardiopulmonary bypass time was 206 minutes. Aortic crossclamp time was $154 \mathrm{mi}-$ nutes. The chest was closed on the following day. The patient was extubated on postoperative day 2 and discharged from the hospital on postoperative day 11 . At 6 months of age, the patient was asymptomatic, had normal feeding and weight gain, and only trivial truncal valve insufficiency.

\section{DISCUSSION}

We have previously demonstrated that anomalous coronary anatomy was a risk factor for death after truncus arteriosus repair. ${ }^{1}$ Although the intramural course of the LCA is rare, the influence of this anatomy on surgical planning is important and, if not appreciated, may contribute to significant morbidity and mortality. ${ }^{1-3}$ The preoperative diagnosis of an intramural course of the LCA is difficult. ${ }^{2}$ It is rarely associated with quadricuspid aortic valve, the latter is often insufficient. We have also recently demonstrated that most patients with moderate or greater truncal valve insufficiency and a quadricuspid valve will require truncal valve surgery. ${ }^{4}$ Although successful repair of truncal valve can be achieved in neonates, ${ }^{4,5}$ concomitant intramural course of the LCA and quadricuspid valvular anatomy, requiring unroofing of the coronary artery with partial valvular resection and reduction of the annulus, is challenging. This report illustrates that successful repair of the truncal valve can be achieved in a neonate despite quadricuspid anatomy and concomitant intramural course of the LCA. Unroofing of the intramural coronary artery combined with the partial resection of the prolapsing cusp with adjacent vascular wall permitted effective reduction of the neoaortic root and provided an excellent early result in our patient.

\section{References}

1. Naimo PS, Fricke TA, Yong MS, d'Udekem Y, Kelly A, Radford DJ, et al. Outcomes of truncus arteriosus repair in children: 35 years of experience from a single institution. Semin Thorac Cardiovasc Surg. 2016;28:500-11.

2. Mir A, Burkhart HM, Ponniah K, Ward K. Intramural coronary artery in truncus arteriosus: importance of preoperative echocardiographic diagnosis and impact on surgical planning. World J Pediatr Congenit Heart Surg. 2018;9:368-70.

3. Hussein N, Speggiorin S, Bu'Lock F, Corno AF. Intramural left coronary artery in truncus arteriosus. World J Pediatr Congenit Heart Surg. 2018;9:117-20.

4. Naimo PS, Fricke TA, d'Udekem Y, Brink J, Weintraub RG, Brizard CP, et al Impact of truncal valve surgery on the outcomes of the truncus arteriosus repair. Eur J Cardiothorac Surg. 2018;54:524-31.

5. Imamura M, Drummond-Webb JJ, Sarris GE, Mee RB. Improving early and intermediate results of truncus arteriosus repair: a new technique of truncal valve repair. Ann Thorac Surg. 1999;67:1142-6. 